\title{
MAKING MARKETS: INFORMATION AND PARODY IN VICTORIAN COMMERCIAL REPRESENTATION
}

\author{
By Aeron Hunt
}

IN THE EARLY MONTHS OF 2012 excitement built for the initial public offering of Facebook, the behemoth social media company with the boy-wonder CEO. Two days before shares began trading on May 18, the IPO was expected to generate $\$ 16$ billion for the company, placing it third after General Motors and Visa in the list of largest IPOs in the United States to that date. In the "frenzy" leading up to the IPO, the New York Times reported waiting lists at events for potential investors and speculation about where "newly minted Facebook billionaires" would go for a drink, while the company revealed its plans to celebrate with a "hackathon" featuring employee DJs and Red Bull (Rusli and Eavis).

Facebook made its money from the IPO. But when shares closed up just 0.6 percent above the offering price - and then dropped 17 percent below it over the next week - the headlines and discussions changed, with "disaster," "fair play," "legal exposure," and regulation replacing champagne and Red Bull (Nocera; Rusli, Protess, and De La Merced; Henning and Davidoff; Rusli and De La Merced). Regulatory agencies opened investigations into whether Facebook and the banks managing its IPO had shared information differentially, notifying only certain large institutional investors of underwhelming news about ad revenues and potential earnings and thereby creating an uneven market in which individual investors were disadvantaged by their enforced ignorance. Lawsuits were filed (see Henning and Davidoff).

There is, to be sure, a world of difference between the IPO of a twenty-first century social media company and the stock bubbles, company frauds, and failures that we encounter in Victorian literature and history. Nonetheless, I begin with this recent case in order to highlight a theme that persists across the centuries: the unevenness of information in the marketplace and the potential to construct categories of victimization around differential access to knowledge. The ruined widows, orphans, and single female investors who populate accounts of the unruly world of Victorian investment are emblems of victimhood in part because of their relative lack of economic agency, but perhaps even more fundamentally because of their status as innocents lacking the knowledge to participate with any meaningful degree of control. To give one familiar example, when Miss Matty in Elizabeth Gaskell's Cranford receives an invitation to attend the shareholders' meeting of the bank whose collapse will ruin her, she has only one frame of reference through which to receive it: as a social invitation. Excited by the acknowledgement she feels herself to be receiving - " it 
is very attentive of them to remember me"" - she shops for silk to make a new dress for the event, underscoring her misapprehension with the confession, "'I don't pretend to understand business"" $(172,177$; ch. 13). Legislative responses to economic volatility often framed the instability of the market as a problem with informational solutions, for instance mandating the reporting of names and addresses of company officers on investment prospectuses; or requiring annual reports and shareholder meetings from which investors could learn about the financial standing and the recent performance of the companies they invested in; or seeking new ways to inform the public about bankruptcies, so that individuals would have better knowledge of their potential business associates (see Hunt; Poovey 2002, 2008). And, as Mary Poovey has suggested, genres of economic writing that purported to be specifically informational developed and were institutionalized over the course of the Victorian period. Financial journalism and professional and trade journals offered new avenues through which to get informed. General interest newspapers and journals expanded their economic reporting. Crowning all, professional economics hardened into an intellectual discipline with increasing authority over money matters (see Poovey 2002, 2008).

However, even as the categories of informed investor and innocent victim developed alongside each other in fictions and nonfictional writing about financial activity, a quite different version of market knowledge emerged that complicates the representation of understanding and ignorance. For many writers of the period, the problem was not so much that the public was unaware of the facts that conditioned the market and shaped its risks. Instead, these writers imagined a substantial public that was informed, aware, and knowledgeable about everyday varieties of honest and dishonest commercial activity even to the point of being complicit in perpetuating a system of market information whose relationship to truth was far from straightforward. In these representations this informational mode was a crucial component in creating an unstable, de-moralized marketplace. Perhaps the definitive Victorian example may be found in Anthony Trollope's account of Melmotte, the shady financier of The Way We Live Now. Though the exact nature of Melmotte's commercial misdeeds is ambiguous, the novel makes it difficult to imagine that those who lost money in the South Central Pacific and Mexican Railway company could have been protected by better information. The claim that Melmotte is "an adventurer and a swindler" is made "openly," according to one character. "There is a consciousness among all who speak of him that he amasses his money not by honest trade, but by unknown tricks" (Trollope, The Way 138; vol. 1, ch. 15). The rumors that precipitate Melmotte's undoing are, effectively, conventional wisdom: the "Evening Pulpit" newspaper publishes a "mysterious paragraph which nobody could understand but they who had known all about it before" (Trollope, The Way 76; vol. 2, ch. 58 ), but the immediately plummeting value of Melmotte's name suggests that "nobody but" denotes a sizable group. The problem is not that Melmotte's public is ignorant, unaware of the information that would ground their investment decisions in truth; instead it is that public's particular brand of knowingness: for the audience of Melmotte's performances, skepticism, cynicism, and a sense for the truth or falsity of information hold little disciplinary force. As Anna Kornbluh has aptly noted in her analysis of financial fictions, because "the mere exposure of ungroundedness does not interrupt figurative circulation," calling out finance as fictitious could have only "diminishing returns": "the ultimate trick of finance was that its artifice did not gainsay its effectivity" (31, 30-31).

This brief account of Melmotte suggests just how complicated the dynamics surrounding market information might be in Victorian Britain, where several different modes of reception 
could govern the public's response, and the binary categories of innocent victims and savvy insiders do not adequately describe the range of possible relationships to an informationmediated marketplace. In this essay I analyze the way these complex dynamics helped shape what Poovey has called the "credit economy" of Victorian Britain. Poovey's Genres of the Credit Economy (2008) presents a rich account of the separation of distinct realms of writing by the nineteenth century, with informational genres defined by claims to facticity splitting off from genres recognized as fictional whose referent was to a formally self-contained standard of verisimilitude. But the persistence of questions about information's role in safeguarding the marketplace and the inadequacy of the division into ignorant and informed market actors suggests that this process of separation bears further investigation, with a field of vision that expands beyond the expert genres - professional economics and literary criticism - to include important, everyday modes of knowledge production and mediation. ${ }^{1}$

I focus here on one of these: parody, a mode of representation, reception, and interpretation common in Victorian representations of the market, even within texts whose primary mode is something else - realist fiction, for instance, or journalistic reporting. I invoke a fairly broad definition of parody, one that doesn't necessarily imply the mimicry of a particular text or genre; instead, I follow Carolyn Williams's recent example, taking parody as a mode that can focus on "cultural formations" such as "social types, behaviors, lines of thought, and institutions" in addition to specific genres or texts (xiii). Theorists of parody have often emphasized its capacity to clarify by confronting pretense and uncovering truths or-during parody's ascendancy as the privileged vehicle of political subversion in the heyday of poststructuralist theory, of which Judith Butler's work offers the best-known example by defamiliarizing and denaturalizing apparently fundamental categories and exposing the conventions through which knowledge comes to appear as such. ${ }^{2}$ But as Dennis Denisoff has argued, parody should not be approached as a unidimensional political aesthetic: it may be deployed by different actors for different purposes, with diffusive and unpredictable effects; and it may constitute multiple coalitions and affiliations in its audiences (2-4). In the discursive field of the marketplace, where knowledge and information were privileged as necessary scaffolding for honest, open, and moral activity, parody's clarifying force was not always self-evident.

Two formal features of parody are of particular interest in analyzing how it mediates the marketplace: first, what Williams has called parody's "rhetoric of temporality" (9); and, second, its tendency toward mutuality in foregrounding the relationship between encoders and decoders. Temporality is at the center of Linda Hutcheon's influential definition, which calls parody "a form of imitation ... characterized by ironic inversion," or "repetition with critical difference" $(6,7)$; Williams underscores that the imitations and repetitions of parody put the present in relation to the past, recalling - and thereby often regenerating or maintaining a spectator's or reader's familiarity with a preexisting formation (see 9). In the Melmotte example I cite above, for instance, it is just as important that Melmotte's audience knows "before" as that it knows "all": because he is a new incarnation of prior formations of the fraudulent financier type - Dickens's Merdle, or any of the real-life models that Trollope might have had in mind - Melmotte would activate parodic interpretive competencies in both his fictional and actual audiences. This dynamic of recognition underlies the mutuality that Hutcheon, especially, emphasizes: a successful parody requires receivers to understand that parody is intended; it is dependent on "certain codes" being "shared between encoder and decoder" (27). Thus, Hutcheon notes, in its formal structure parody "calls attention to the 
presence of both author and reader positions ... and to the manipulating power of some kind of 'authority", (88). But Hutcheon's model does not hold that this " "authority", is isolable in a separate, all-powerful, "real" author; instead, even this "manipulating," intentional parodic agent is an effect of mutuality, "a hypothetical hermeneutical construct inferred or 'postulated' by the reader from the text's inscription" (88). The informational experience that these formal structures mediate aligns producers and consumers, constructing the effect of a unified, homogeneous information market through the impression of already shared knowledge.

This essay analyzes the informational dynamics of market parody in two representational realms. First, I examine representations of commercial activity drawn from performance and popular entertainment, an area that has generated influential perspectives on the critical potential of parody: theatrical representations of commerce, from onstage and off; and examples from the music hall, a space that circulated styles of "knowing" performance and interpretation (see Bailey; Faulk, 12-13). Second, I analyze a literary example, Trollope's parodic commercial exposé, The Struggles of Brown, Jones, and Robinson, By One of the Firm. As parody framed the problem of knowledge in the Victorian marketplace, I suggest, individual subjects and communities came to experience information as something other than a matter of fact that could be mastered through expertise or regulation to serve as a market safeguard. Instead, I suggest, the parodic mode blunted its own critical edge, creating a perspective through which access to information did not plausibly divide the market. Interpellated into "knowing," consumers of market parody were made complicit in economic instability, as co-players in a performance that helped to maintain - even as it denied - the asymmetrical relationships that characterized the volatile, unequal marketplace. Ignorance was not only not an excuse; in the marketplace constructed by parody, it was hardly imagined to be possible.

\section{Performing Business, Parodying Business}

WHETHER THE STOCK OFFERINGS ARE for Facebook or Trollope's South Central Pacific and Mexican Railway, investment requires information. But even as economists assume that "perfect information" forms a crucial foundation to a perfectly working market (Hirschman 1473), in actual markets rather than ideal models the question of what that information entails remains vexing. In fact the informational backdrop of investment might be decidedly mixed, incorporating anything from balance sheets; to events in the news; to the soft data of stories, spread by the press or word of mouth, about a CEO's real estate purchases, social activities, and philanthropic habits - or about a company's cafeteria arrangements and architecturally dazzling campus. Information in the marketplace is, in certain respects, neutral: an enabling medium that may clarify or distort, illuminate or distract.

Many canonical representations of commercial dishonesty in Victorian fiction characterize the distracting or distorting aspect of information - misinformation - in terms of performance. The same action - say, Melmotte's occupying an elaborate townhouse with a fashionable address and hosting a magnificent dinner party for the Chinese emperor may be either a significant fact that tells the potential investor something about the company promoter and his personal financial stability, or an elaborate display undertaken to manipulate the information potential investors would consider. And these representations of commercial dishonesty frequently emphasize the performative aspect of fraud by highlighting the role of audiences in misapprehending the nature of the information these shows convey. In Victorian 
representations fraud is, as often as not, the hottest ticket in town - though, as in Melmotte's case, the price of the "tickets for the entertainment" (Trollope, The Way 97; vol. 2, ch. 61) is subject to a sudden tumble. ${ }^{3}$

But in a wider context this association of duplicity and performance-according to which performance is defined as distorting the informational field - was not so straightforward. After all, as historians have emphasized, onstage performance in the Victorian period was very often unconcerned with establishing truth through verisimilitude, with gestures to an apparent reality offered up behind an invisible fourth wall. Instead Victorian performance frequently offered acknowledgements of theatricality and reveled in the interplay between performers and audiences (see Auerbach 6; Donohue 21). In venues such as theaters and music halls performers underscored their audiences' knowingness, engaging in a parodic mode of performance that did not imply fakery or the concealment of truth but rather made the fact of performance part of the information that was assumed, shared, and regenerated.

Including examples of staged performance thus adds nuance to our account of the expectations that Victorians might have brought to the performance of commerce - onstage and off - and to our understanding of Victorian commercial information and the genres that mediated it, complicating the model that separates information and fiction. ${ }^{4}$ In this section I analyze the promotional materials of popular theatrical entrepreneurs, stage representations of commercial activity, and performances of commercial activity from the music hall, highlighting representations and styles of commercial performance that self-consciously emphasize the relationship and mutual recognition of performance (and performers) and audience. The parodic mode in these performance genres does not merely expose falsehood or reveal an unacknowledged profit motive, an information dynamic that would shore up the line between truth and untruth that could be imagined to organize a properly functioning economic system. Instead, by invoking knowingness these parodies construct their audience as a market that is always already informed about fictionality and reshape conventions of information in a way that undermines its promise as a tool to promote economic rationality, predictability, and safety.

In what sense should Victorian audiences - those in attendance in commercial performance spaces such as theaters and music halls - be described as "knowing"? More to the point, bearing in mind Hutcheon's and Williams's emphasis on parody's essential temporality, what kinds of knowledge connecting performance to commerce did audiences bring with them? In the first place, they knew - or at least they were informed - that they were participating in a social exchange that was both frankly entertaining and, quite often, frankly commercial. Playbills beckoned ticket buyers not just with enticing images, large-print names of star performers, and tantalizing titles; they also promised a chance to participate, literally as well as figuratively, in show business. A playbill from Astley's, for instance, highlights its offering of the "highly successful and popular spectacle" of Byron's Mazeppa, performed with "brilliant equestrian achievements" and the impressive physical specimens depicted on the bill (Figure 26). ${ }^{5}$ But in urging the public to come to the show for what are "positively the last 5 nights of the season" the bill also highlights a business matter: the approaching end of "Mr. Batty's management." William Batty, Astley's lessee, is an attraction in the bill; his managerial skills, his capacity to judge and supply the tastes of the public are invoked as an integral part of the show and its pleasures. A playbill for the Bower Saloon, a cheap theater in Lambeth, creates an even more complicated exchange between prospective audience and manager (Figure 27). On this benefit night for Mr. W. Dean a lighthearted verse jokes 


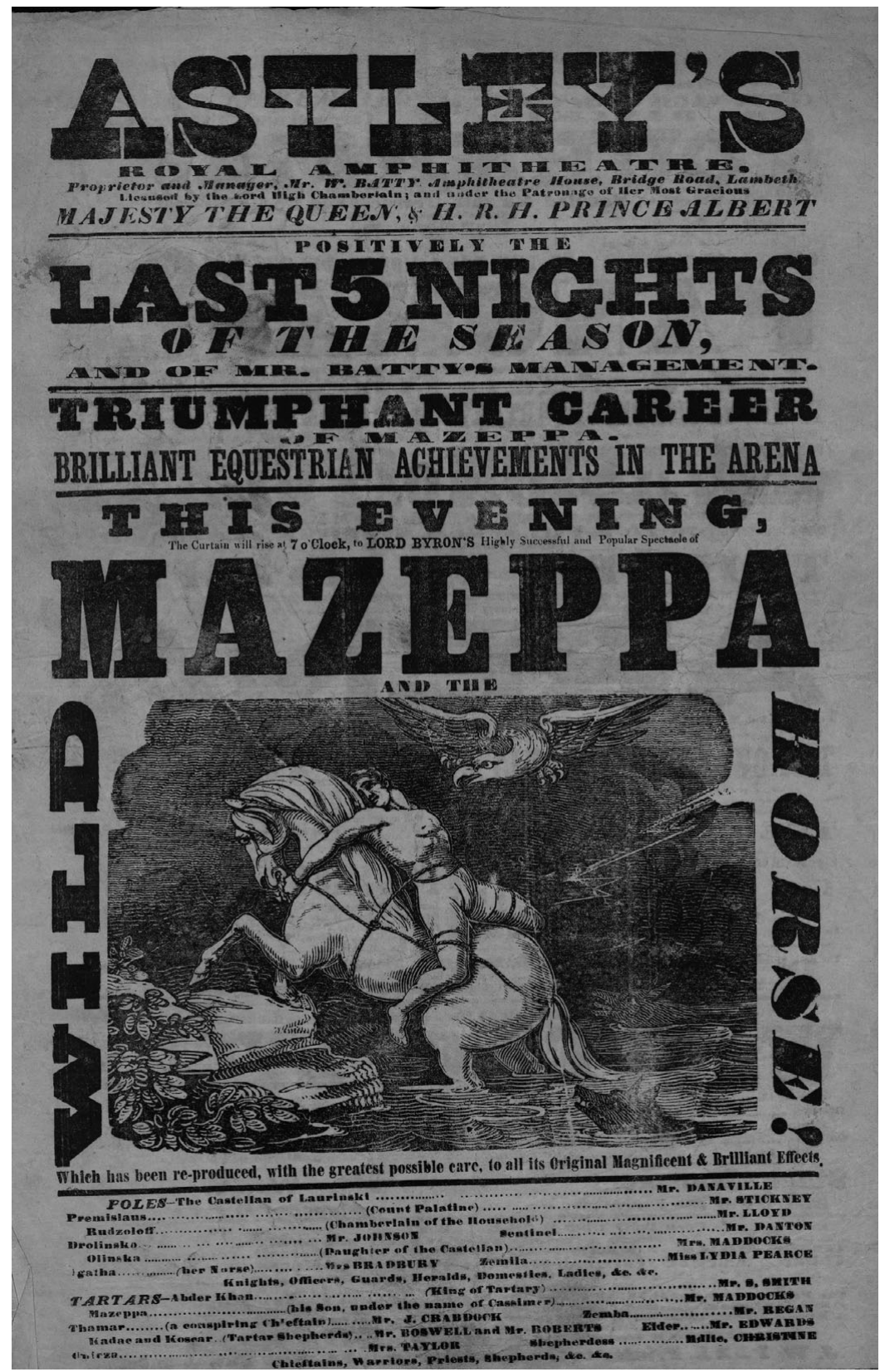

Figure 26. Playbill, Astley's Royal Amphitheatre (London, n.d.). Harry Ransom Center. The University of Texas at Austin. 


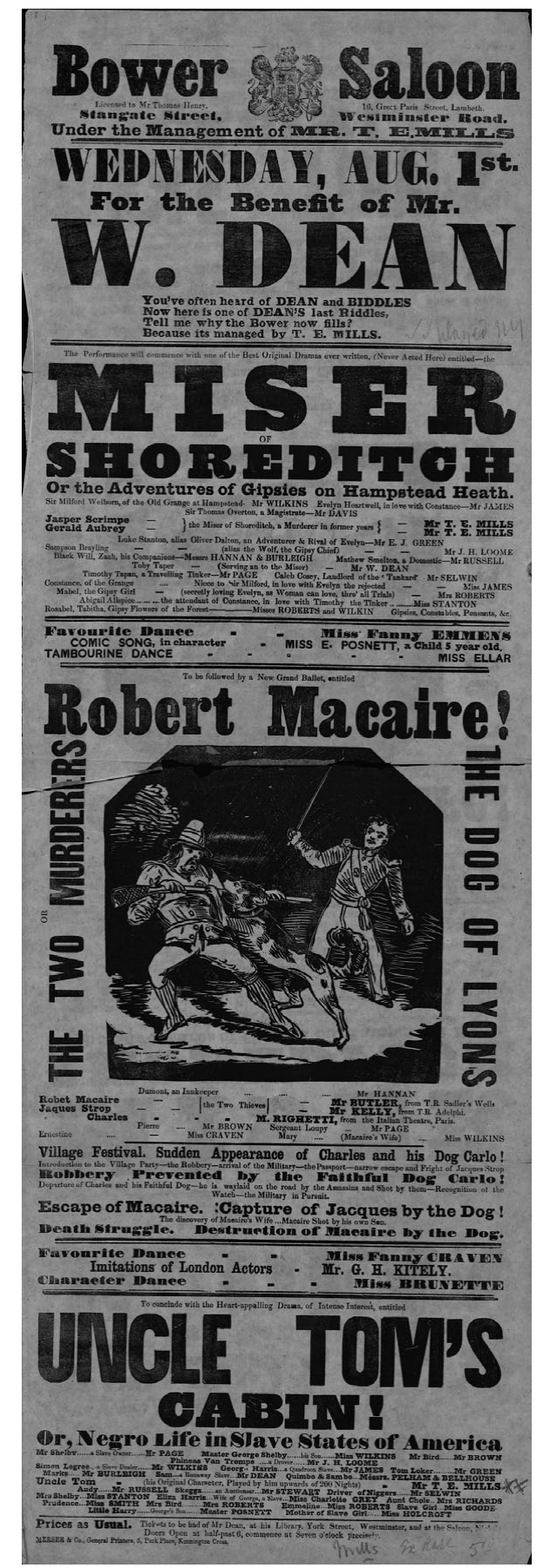

Figure 27. Playbill, Bower Saloon (London, n.d.). Harry Ransom Center. The University of Texas at Austin. 


\author{
You've often heard of DEAN and BIDDLES \\ Now here is one of DEAN's last Riddles, \\ Tell me why the Bower now fills? \\ Because its [sic] managed by T. E. Mills. (Bower)
}

Dean and Biddles, both managers of the Bower, and the management of the theater more generally become part of a playful, promotional jest in which a manager's success in attracting an audience is part of the appeal to attract a new audience. Managers' names stand alongside those of performers (Mills), and if the bill's joke turns on the superior entertainment provision of the latter, its teasing humor presumes the audience's familiarity with and pleasure in commercial showmanship. ${ }^{6}$

Examples such as these begin to suggest that it is inadequate to take as a given the association of performance and duplicity, and the informational pattern that it organizes, in which performance hides commercial truths from unwary innocents. The audience of these playbills is addressed, constituted, and made aware of its collective identity at least in part through an overtly commercial appeal. In fact, the forthright blending of performance and commerce reached into many different aspects of the entertainment scene. In music hall the border between stage and business was notably blurry. The "chairman" of the early music hall represents a case in point, as the proprietor himself - or a figure who purported to act as intermediary among audience, performers, and proprietor - urged on the audience to convivial chorus singing and remunerative drinking (see Garrett; Bailey, "Custom"). ${ }^{7}$ The celebrated promoters of the later music hall - often discussed as pathbreakers in the project of industrializing entertainment - built their commercial personae on the example of this earlier figure, hyping their entrepreneurial skill and their connection to their audience all at once. ${ }^{8}$ The effects of this linkage were multiple and contradictory. On the one hand, invoking the more intimate commercial/communitarian associations of the early chairmen downplayed the capitalist entrepreneurialism of the new promoters. When Charles Morton, the figure behind the first large-scale, purpose-built music hall (the Canterbury) styled himself "Father of the Halls" (Figure 28), or when William Holland, the so-called People's William, produced "programme after programme, production after production," "always adding at the end of each printed bill or poster, 'Your obedient caterer, William Holland"' (Newton 88 ), they adopted familiar terms which deemphasize payments and profits. But on the other hand, even as these promotional identities disavowed strictly commercial motivations, they focused attention squarely upon the entrepreneurs themselves and the managerial activities that might have otherwise remained offstage. Thus in a 1904 souvenir program for a benefit for his widow (Figure 28), Morton sits in a manner reminiscent of the early chairmen at a table, larger than life and surrounded by the singers and dancers he engaged: he is part of the show and greater than it; all at once a promoter, a performer, and a participant in a community within which exchange occurred on terms of friendship and profit.

A crucial feature in the business of Victorian performance, in other words, was the acknowledgement of performance and business simultaneously: performance and show were not necessarily seen as cover-ups for moneymaking interests, and the show-business entrepreneurial persona acknowledged the association and kept it in view. Thus Idols of the 'Halls,' a 1928 music-hall memoir by H. Chance Newton, mentions managers in the subject lists of eight of its twenty-one chapters, construing them as stars along with the singers. And just as managers are described through the same celebrity lens as stage performers, 


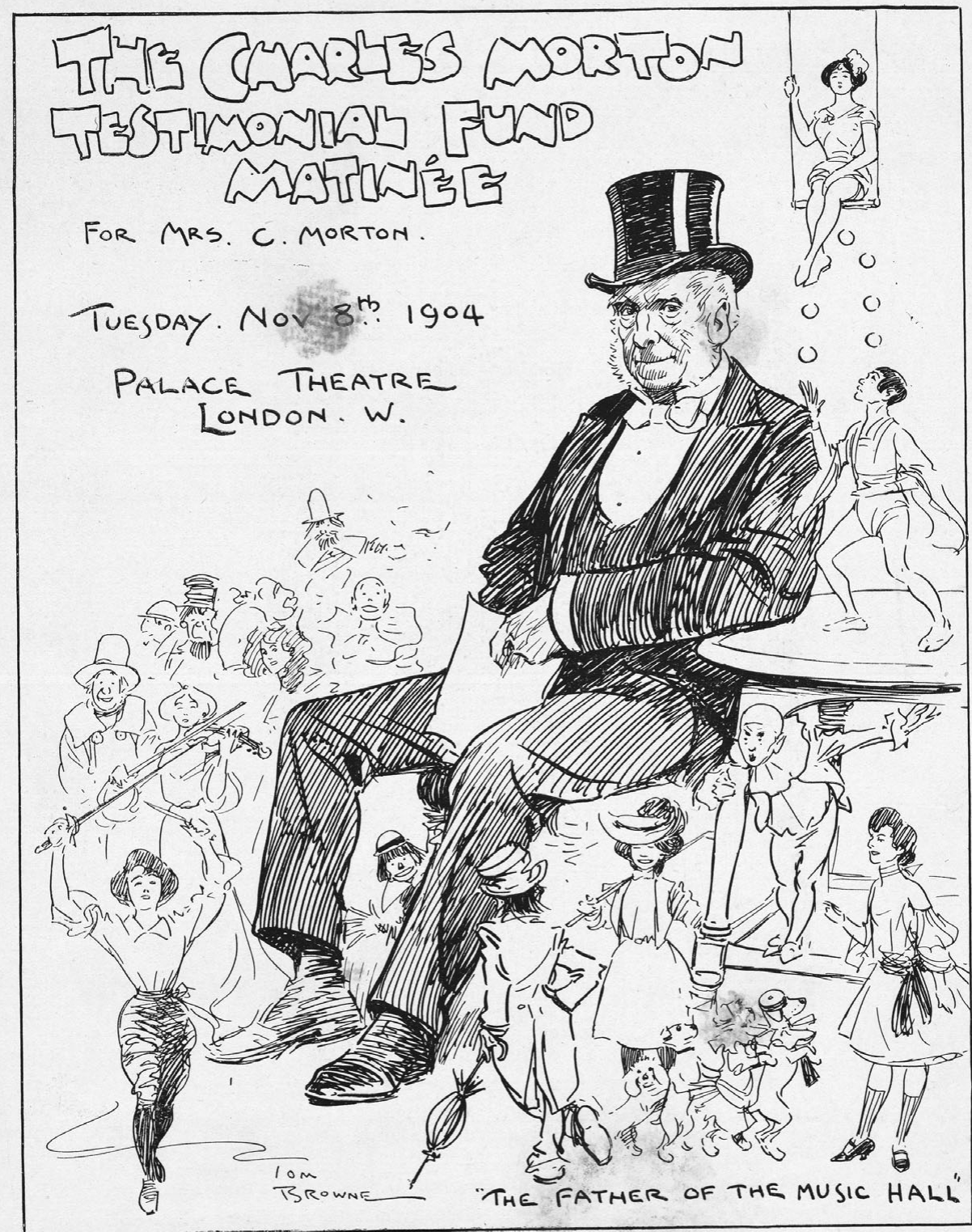

TOM BROWNE

Figure 28. Frontispiece, souvenir program. Charles Morton Testimonial (London, 1904). Harry Ransom Center. The University of Texas at Austin. 
stage performers are also discussed as businesspeople, celebrated for their salaries and their commercial sharpness. The Great Macdermott, the lion comique, receives praise for his stage talents but also for the "song bargains" that he managed, for instance when he bought "the Jingo song" - the famously nationalistic assertion of British military readiness - "for a guinea" (Newton 78). As another account, Percy Fitzgerald's Music Hall Land, suggests, the self-promotion that is a hallmark of the performers' styles (in soubriquets such as "The Great" Macdermott's) centers as much on a representation of commercial success as on their particular performance talents. "In the music-hall country the public is taken into confidence" with an announcement of the performer's career success. "The grand triumph is to announce that you are 'engaged' or re-engaged, or have been engaged for months, that is 'all dates are filled"' (Fitzgerald 65). Performance and commercial activity bleed into each other, with commercial skill and success celebrated just as a flair for impersonation or a way with a chorus would be. ${ }^{9}$ Fitzgerald's text is double edged: its commercial frankness (the performers are out for success, measured in bookings and tickets) incorporates an acknowledgement that information is being manipulated to keep up one's market appeal. However any threat this manipulation might imply is foreclosed: the public is sharp and savvy, aware of what is meant by each nuance in the performer or promoter's self-advertisement. Their knowingness signaled by scare quotes, they read a "'resting"” performer as a performer in trouble: out of demand and available for bookings. The canny audience that Fitzgerald depicts may be "taken into confidence," but it will never be fully taken in by the manipulation of information, even if that manipulation helps to support the desired commercial effect.

In the emerging Victorian entertainment industry, therefore, the blending of economic motivations, actions, and performances was a recognized aspect of commercial personae and a commonplace part of the representations that audiences encountered, to the point where subjects in the audience are assumed to share in enjoyment of the frankly commercial and where it becomes available for parodic representation. This is not to say that all notion of distinguishing commercial truth and falsehood vanished, either in the contexts of performance or in the wider world of investment and commercial affairs where stock tables, balance sheets, and economic reporting were taken to aspire properly to accuracy. Nor is it to suggest that stage performances of various genres could not cast a critically distanced perspective on the commercial duplicity of the day. When music hall topical songs commented upon the business news, for instance, they called upon the audience to unite in condemning fraud. In the character song "Billy Barlow," one of many instances of pointed reference to commercial scandal, the singer voices a poor man's complaint about commercial abuses and judicial inequities. Referring to the heads of a private banking firm whose bankruptcy and misappropriation of funds caused a great stir in the mid-1850s, the character complains of the "fourteen years" that had been given to Strahan, Paul, and Bates as punishment for a crime that the song does not sugarcoat: "With the tin of their customers they'd made away." Using the low language of ordinary crime (and advocating a harsher justice, with "ropes" to send the bankers "off at eight"), the song's language is designed to clarify and expose, placing the white-collar crime in its proper category with appropriately low language ("Billy Barlow").

But other performances take a more complex stance toward their revelations. The song sheet cover to "They're All Very Fine and Large" (Figure 29) trumpets that it has been "sung with immense success by Herbert Campbell" - standard-issue bragging for musichall promotional materials. The song's lyrics, however, comment on the familiar boastful 


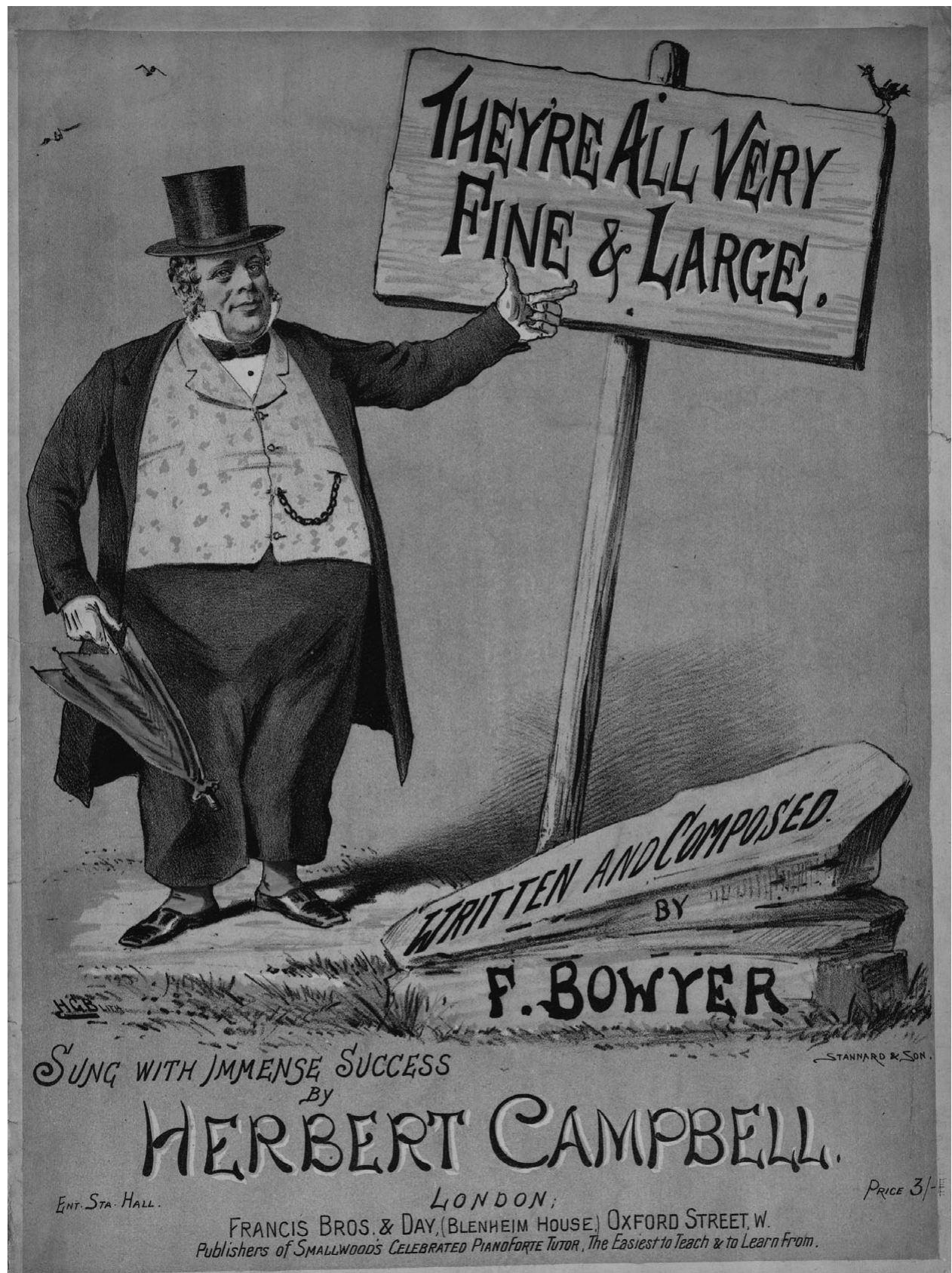

Figure 29. Song sheet cover. Bowyer, F. "They're All Very Fine and Large” (London, n.d.). Harry Ransom Center. The University of Texas at Austin. 
mode in which the song has been offered, detailing the exaggerations of advertising, and acknowledging its rhetorical purposes and its tenuous relation to the truth:

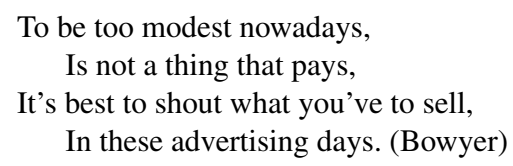

Gone is the distance from which "Billy Barlow" critiqued commercial falseness. Instead, song and performer implicate themselves - and, significantly, the audience:

I say this song is something great!

To ventilate your wrongs,

But as to that, you all know well,

That nearly all my songs.

They're all very fine and large,

They're fat, they're sound and prime,

They're the widest in creation,

And I make no extra charge,

Now who'll have a chance for a dozen or two,

They're all very fine and large. (Bowyer)

As the song shouts its virtues, acknowledging the commercial motivation for doing so, it winks at its falseness or exaggeration. The shabby sign to which the singer points on the song sheet cover undermines the grandiose claims made by his words and dress. The verse's "nearly all" becomes the chorus's "all" the songs, and the audience - "you all" - is acknowledged to be in on the game, aware that if they "have a chance for a dozen or two," they may not be getting just what is advertised. Finally, the choice of words "very fine and large" - while allowing for racy wordplay in some of the other verses - works in precisely the opposite way to "Billy Barlow." Where that lyric aimed to clarify and expose, the parodic mode in which this song operates suggests that fully participating in a commercial transaction, as the audience does with the singer, may involve knowingly accepting language that plays with the line between truth and falsehood. What does it mean, exactly, for a song to be "large"? The lyrics jettison sensible description, invoking instead a standard of value - bulk - that derives what meaning it has primarily from the empty advertising claims that the song acknowledges, mocks, and repeats, secure in the audience's recognition of the forms and languages on which the humor depends.

A final song example - a character song sung in the persona of the Artful Dodger on his way to prison - brings together the different modes of onstage parody and exposure, suggesting the way that the play with "knowingness" in music hall performance constructs a complex, conditional judgment on the potential power of an informed public. The verses draw a link between the Dodger's theft of "vipes" and famous contemporary white-collar swindles practiced through railway investments and the Crystal Palace and Royal British Bank frauds. At the end of the song the Dodger has returned from his incarceration, and he updates his audience on his plans following the learning opportunities afforded by prison:

Of all the little games just now,

There's one as takes first rank, 
So I've been to get Directors

For a Royal Dodger Bank! (Sloman and Cowell)

The song follows this topical critique by linking the interactive space of the hall and its promoters and performers to the conduct of commercial fraud:

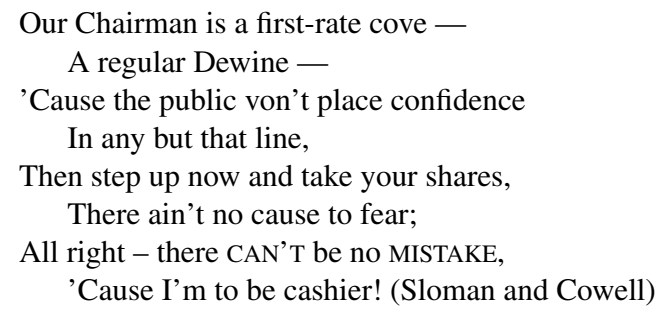

"The Artful Dodger" raises the question of trust with a wink, assuming that the audience knows not to "place confidence" but derives pleasure from the performer's willingness to flout the norms of truth and belief that that are expected to ground a secure exchange. Informed enough to get the jokes parading the Dodger's familiar and dubious character, the audience continues to pay for songs and drinks (as for "shares"). The wink acknowledging and demanding recognition constructs that payment as consent to the possibility of a swindle.

Scholars such as Peter Bailey and Barry Faulk have taken this knowingness as perhaps the most characteristic mode in the heterogeneous form that is music hall (Bailey; Faulk 1213). ${ }^{10}$ While the association of music hall with parody and "knowingness" and its reputation as a vanguard form of the industrialization of entertainment make it an especially obvious analytical site, dramatic representations of commerce such as George Henry Lewes's comedy The Game of Speculation (first performed at the Lyceum Theatre, London, in 1851) play with a similar parodic informational dynamic. From the directly informative title, to the forthrightly descriptive character names - which include Affable Hawk, the play's antihero, whose income depends on pumping and prolonging the speculations that give the play its title; his old friend and co-conspirator/dupe, Mr. Prospectus; and his creditors, Hardcore and Grossmark (Loosefish and Shark in the licensed manuscript version) - the play's parodic gestures work by invoking an assumed familiarity with commercial types, actions, and narratives. In onstage action duplicity is acknowledged to such a degree that concealment is not in question: Hawk's schemes to manipulate the value of investments are openly discussed, and the audience is privy to the tricks he plans. Moreover, these so-called games are described using a theatrical vocabulary that, as Jane Moody suggests, produces a "self-conscious convergence and playful collusion of capitalism and performance" (93). From the first scene, in which Hawk's servants discuss the particular job duties required in a household such as his, performance is foregrounded. As the servant Mrs. Dimity announces,

\footnotetext{
I have been lady's maid in a great many families, but never in such as this. One has to become quite an actress! A creditor arrives - you have to throw astonishment into your eyebrows, and exclaim "What! you don't know, sir?" "Know what?" "Mr. Affable Hawk is gone to Manchester, about some new speculation." "Oh! gone to Manchester, is he?" "Yes, sir, a splendid affair, I hear - discovery of a copper mine." "So much the better! When does he come back?" "Really, sir, we don't know." . .
} 
He's settled! But what a countenance it requires to lie with that superiority! And my wages are none the higher for it. (226)

Audience members, witnessing this exchange, become better informed than at least some of the characters onstage, clued in to the deceptions being practiced and the strategies involved in the "game" of speculation that the title has already announced. But even as they recognize the onstage falsehoods, they take pleasure in the performance, simultaneously experiencing and disavowing in their suspended disbelief the reactions of the onstage dupes. Positioned as savvy about the gap between performance and truth, the audience's situation is one in which being informed loses its meaning. The collective experience imagined through the play's parodic gestures and staging is one in which "everybody knows." The audience can't say it wasn't warned: in fact, the play's dependence on the temporality of parody - demanding from the start audience recognition that speculation is a game, that characters are hawks or sharks - implies that a warning was never even really necessary.

To illustrate this potential, I offer a brief analysis of how the dynamics of parodic representation played out around situations of commercial performance from outside the context of entertainment. I focus on shareholder meetings, one of many ritualized commercial events that provided occasions for a kind of stage business (board meetings and testimonial dinners would be other possible examples), in part because it is possible to compare their representation in "straight" journalistic reporting and in the many parodies of commercial practice in which they feature prominently. More significant for my purposes is the particularif fraught - role they were expected to play as a vehicle for information, as company leaders offered reports and their shareholder audiences were able to exchange criticism and ask questions, all of which might be reported by the press. Shareholder meetings, then, were occasions when marketplace information was negotiated and potentially contested, and the questions of who knows what, and when and how they know it, take on particular salience.

The informational aspect of shareholder meetings receives a great deal of attention in journalistic representations - attention that vacillates between more-or-less stenographic reporting of the information that companies present as they make their reports to the assembly, and anxious consideration of the informational contexts and audiences. The London Review in 1864 blended both tendencies in its report, "The Half-Yearly Railway Meetings," mixing its accounts of the reported earnings, losses, activities and acquisitions, dividends, and so forth, with an editorial comment suggesting that the broader audience for this information may not be sufficiently engaged to receive it or to pull the information together into the proper (in the writer's view, celebratory) narrative: "The reports and speeches of the half-yearly meetings may appear dry and repulsive to the general reader, but they really supply a most interesting chapter of social progress and commercial enterprise, as well as striking evidence of the growth of our national resources" (215). But the critical perspective on commercial information also targeted the practices of companies themselves, as well as the press. In an 1878 Fraser's Magazine article, for instance, F. R. Conder decried the dismal state of knowledge about the commercial aspects of railways on the part of shareholders, managers, public officials and the broader public alike, suggesting that the country was "carrying on an enormous traffic in utter ignorance of its commercial conditions" (501). With a "large amount of national interest" - not to mention dividend profits - "at stake" in this critical industry, "the shareholders, Parliament, and the public are still content to remain in absolute ignorance of the relative profit or loss of the various kinds of work carried on by the railway companies" 
(491). The close of the half-yearly railway meetings is the occasion for Conder's complaint; these typified the low standards of an information system marked by complacent, sanguine insularity: "The railway chairmen congratulated the shareholders on the good result, in a season of admitted commercial depression. The railway newspapers echo the congratulations; and the press in general, led in such matters rather by Stock Exchange rumours than by any special study of the subject, declares the result to be satisfactory" (490).

In Conder's characterization, the shareholders are spoken to, their perspective foreclosed as the chairmen enlist them, in a pre-emptively self-congratulatory move, as nominal recipients of a "good result." Such audience complacency was not uniform, however, and other accounts of shareholder meetings represent a more combustible or anxious scene in which the limits of information are explicitly questioned from many different angles. In an 1864 meeting of the Eastern Counties Railway, for instance, one shareholder seems to have reframed the directors' account in both material and political ways. In a discussion of the company's ledger, the shareholder "pointed out" the dodge of counting a $£ 3,733$ sum earned from working a new line as a "gain," when its share of liability for an accident on the line was $£ 6,529$. Redescribing this as a "gain of a loss,", the shareholder then goes on to wonder whether "the accident "did not arise from want of vigilance and from working the railway servants too many hours"" (215). Quoting the shareholder, the journalist enters this new interpretation into the public record, transforming an accounting detail into a matter of corporate responsibility and labor practice, and then goes on to highlight the potential service provided by such clarifying, challenging exchanges between presenters and their audiences: "If Boards were not made to smart for railway accidents, would not the lives of the public be still more endangered by this species of cruel and short-sighted economy?" (215). The encounter between audience and directors, in this case at least, fulfills its potential to disrupt the careful management of information.

Just how common or how broadly effective such moments were is, of course, a question; but the degree of preoccupation with the management of information in accounts of shareholder meetings suggest that directors were concerned about their possibility. In many accounts directors and journalists alike are exceptionally alert to the issue of information asymmetry in companies with more technologically or operationally complex missions. In 1871, for instance, the Saturday Review reported on a meeting of the shareholders of two railway companies planning amalgamation, endorsing the observation of a chairman of one company that "it is impossible for an ordinary shareholder to form an independent opinion on complicated and important questions of railway policy. The governing bodies of Joint-Stock Companies must be trusted like other professional agents to understand the interests which they protect better than the principals themselves" ("Railway Amalgamation" 544). The intrinsically superior knowledge - and consequent privilege to tell their own tale, without challenge - claimed by directors was assisted by what the Edinburgh Review called an "assumption of offended dignity" when "disagreeable criticisms and objections" were raised by shareholders in the purportedly "democratic" venue of the shareholder meeting. The chairman's response, "that if the shareholders cannot trust his colleagues and himself, they had better choose others" to lead the company, "tells," so that the concerns of the proprietary don't ultimately carry the day ("Reports from the Select Committee" 421, 421, $420,421,421) .{ }^{11}$ At other moments, the desire to keep information under control is prompted by business concerns; discussing a proposed amalgamation of their railway companies, the directors note the relative openness of the public meeting as a risk: "The proprietors of the 
two Companies have good reason to believe, on general grounds and on the authority of their Boards, that the amalgamation will, other things being equal, increase the value of their shares. Whether other things will be equal, or, in other words, what price they may have to pay for the proposed benefit, was a question which could not be prudently discussed in the presence of a mixed audience and of newspaper reporters" (544).

The conflict over information in examples such as these-simmering, deflected, potential, or open - stands in contrast to the portrayal of such meetings in parodic representations. In "How We 'Floated' the Trixie Gold Mine Co. (Limited)," a fiction written in the voice of the secretary of a new joint-stock company, Malcolm Laing-Meason describes a public that is "more than half prepared to believe" the rosy projections of directors in a prospectus that "did not actually state falsehoods, but . . . economised the truth" (50); the "certificates from leading engineers" testifying to the wealth of gold waiting to be plucked with ease from the ground (49); the chunks of gold-flecked rock - manufactured around the corner in London that appeared to give material confirmation; the "financial columns" and "imaginary letters from South America" (50) that enlisted the press in an information campaign. At a half-yearly meeting - usually "thinly attended" (51) - one shareholder asks for more specific information about the genuineness of the reports and the prospect that the company will pay a dividend; when the directors quickly "put their heads together" to come up with a reply, they brashly announce a dividend of at least 10 to 15 percent, to be paid within two months. The rest of the shareholder audience at the meeting applauds the directors upon hearing this news of their own good fortune, and prompt the directors to scold the skeptic for "“crying stinking fish"” about the property in which he had an interest $(53,54)$.

In this account, the live encounter between shareholders and directors is notable not for the possibility of clarification and exposure, which is raised and denied, but rather for the complicity of the public in effecting this denial. The public is, after all, choosing to "half believe" - and in practice lend support to - an enterprise structured on the parodic principle of knowing it all before. From the company's name (Trixie) to its officers, who include the chairman Lord Bunkum, the solicitors Regal and Chance, and Mr. Fraud, who is also, improbably, "a director of the Fiji Islands Tramcar Company" (45), insofar as the parodic representation gives readers and fictional shareholders access to similar information - that is, not the back story that only readers could know, but the information that the company itself promotes to characters within the narrative - there is no essential learning to be done, nothing withheld that must be revealed through time. Within the narrative, none of the market subject positions make sense, in informational terms. The applauding crowds at the halfyearly meeting have consented to overlook the norms of truth and falsehood in the name of perpetuating their self-interest, but the skeptical questioner, superficially perceptive, is in fact obtuse, unable to recognize that the questions he asks are beside the point: he already knows.

Though this parody, then, in one sense presents itself as a vehicle for exposure, revealing the tricks of the Trixie mining company and by extension other unscrupulous speculative ventures, in another sense its temporal rhetoric forecloses the power of information. That access to information is asymmetrical, that important details may be hidden or mischaracterized - and that shareholders or a broader public might diagnose their informational disadvantage and demand a more equal playing field and a voice in shaping how corporate information was represented and understood, as happened in actual shareholder meetings: recognizing these features and having the critique they imply take hold becomes, paradoxically, more difficult through the parodic model. As parodies construct audiences and 
readers as markets (and markets as audiences and readers), the knowingness on which they depend risks overloading responsibility for the morality and security of the marketplace onto its less powerful participants, characterized as buyers who did not sufficiently beware, or who - consciously or semi-consciously - consented to be duped.

\section{Behind the Scenes: Trollope's Commercial Parody}

IF MELMOTTE HAS BECOME a byword for spectacular Victorian commercial fraud, the more pedestrian scam artists in Trollope's 1861-62 short novel, The Struggles of Brown, Jones, and Robinson, By One of the Firm, have remained small. In his autobiography Trollope called the novel "the hardest bargain I ever sold to a publisher," and while many factors unrelated to the novel's merits contributed to this difficulty, his comment probably will not surprise anyone who has slogged through its narrative of dishonesty at a haberdashery firm (106). ${ }^{12}$ Trollope struggles to evaluate it at greater length, weighing his own sense of the novel's virtues and failings against the public's:

I attempted a style for which I certainly was not qualified, and to which I never again had recourse. It was meant to be funny, was full of slang, and was intended as a satire on the ways of trade. Still, I think there is some good fun in it, but I have heard no one else express such an opinion. I do not know that I ever heard any opinion expressed on it, - except by the publisher who kindly remarked that he did not think it was equal to my usual work. ... I do not know that it was ever criticised or ever read. I received $£ 600$ for it. (105-6)

Trollope may have been disingenuous in proclaiming ignorance of reviews and commentaries: the Saturday Review, for one, held that "the chief characters, motives, and incidents" of The Struggles of Brown, Jones, and Robinson "were so odiously vulgar and stupid that the staunchest champions of realism were forced to give it up in disgust."13

If Trollope, his reviewers and publisher, and the public seem to be in relative agreement that the novel isn't his best, there is less unanimity on what kind of novel it is. In contrast to the reviewer's categorization of the novel as realist, on the grounds of its treatment of low, ugly subjects, Trollope emphasizes its generic and stylistic experimentation and its distinction from his usual, self-described straightforward, plain-spoken realism. In fact, The Struggles of Brown, Jones, and Robinson, By One of the Firm is a departure in many respects. The voice of its first-person narrator, Robinson, couldn't be further from Trollope's reassuring, trustworthy, companionable omniscience. Rather than depicting the ordinary with a determined absence of flash, The Struggles of Brown, Jones, and Robinson ventures into satirical comic exaggeration. More precisely, Trollope works in the mode of parody - mocking not merely the dishonest business practices of his day, but also a genre, the business exposé, that was intended to reveal them. ${ }^{14}$

In this final section, I examine what this experiment with parody suggests about the genre's potential as a textual negotiation of market information and market relationships. Trollope himself was, of course, exceptionally alert to commercial relations and the role of information within them, gaining notoriety (and losing reputation) for the use he made of information - and an informational aesthetic - in his autobiography as he scrupulously demystified his compositional practice and forthrightly announced his interest in making money through his writing, to the point of concluding with an accounting of the sums he had 
received for each novel. His effort to present himself as an honest tradesman and laborer, giving quantifiable value with metrics of words and time, might be read as a strategy for creating a compact with the readers who form his market that is structured according to principles of transparent, equal information. It is a strategy Trollope adopted in other ventures that were simultaneously commercial and literary. In the course of editing St. Paul's Magazine, for instance, Trollope's opening editorial was frank about the for-profit motivations of the undertaking, announcing that the journal was " "not established ... on any rooted and matured conviction that such a periodical is the great and pressing want of the age" " but rather because the proprietors believed it could be "commercially profitable"” (Hall, Trollope 309-10).

Trollope, in other words, tries at different points in his career to address his market in such scrupulously direct terms that the very form of the business exposé would be superfluous: there is no informational mismatch; nothing must be exposed because nothing is held back. The relationship between audience and producer/seller that he deliberately constructs - one in which the phrase "we all know" is operative - is the one that parody assumes in its manner of addressing its audience. The step that Trollope takes is significant, as it acknowledges the possibility that this full sharing may not be present - and that the responsibility to make sure that honest accountings of commercial motivations, practices, and so forth occur belongs to the producer, promoter, or seller, not just the wary consumer, investor, or buyer.

When Trollope turns to parody the dishonest practices of Magenta House, the retail establishment of The Struggles of Brown, Jones, and Robinson, and the business genres that purported to offer revelations, the relative weakness of parody's critical edge becomes apparent as the complicity of public and business in maintaining profitable dishonesty becomes an extended theme. Robinson, the firm's ad writer and the memoir's narrator, makes a success of the business through two strategies: advertising exaggerated quantities and nonexistent exotic goods - eight thousand African monkey muffs, for instance; and constructing his advertisements as narratives in little magenta-covered books, long stories, and serial narratives about the firm itself that thrill and fascinate consumers. A high point in the existence of Magenta House comes with Robinson's manipulation of a brief conflict with a supplier, Johnson of Manchester, who because of a strike is unable to get supplies to them, into an extended narrative that leaves the public breathlessly awaiting the next episode in a story in which the firm is the aggrieved hero. So great an éclat does this produce that letters appear in the paper from merchants in Manchester denying that they are the models for the villain, while "the conduct of Johnson, and his probable fate, were discussed aloud among those who believed in him, while they who were incredulous communicated their want of faith to each other in whispers" (86). Robinson demonstrates an uncanny sense of the limit of the public's fascination, as he promises a resolution to the story - "Brown, Jones, and Robinson beg to assure the public that they shall be put out of all suspense early on Monday morning" (Trollope 89; ch. 11) - but never supplies it, on the (correct) theory that interest will have waned by that point. But the story - or its demonstration of the firm's ability to tap into a public mind - does its job. Even those fellow tradesmen who don't believe the Johnson story give the firm credit for it, with both financing and admiration.

If the marketing of falsehoods to a public ready to be enthralled opens the possibility of criticizing the purveyors of the falsehoods, the novel goes on to elaborate an argument that casts responsibility much more broadly. In a conversation among the members of the firm Robinson suggests that a consensus exists to understand and tolerate a certain amount of dishonesty in business, which allows language that deviates from norms of truth-telling 
(such as these stories, or other advertisements) to be commercially effective even if no one really believes it. When Brown objects to an advertisement on the grounds that he hasn't got the goods, Robinson retorts:

\begin{abstract}
"True! . . . You wish that it should be true! In the first place, did you ever see an advertisement that contained the truth? If it were as true as heaven, would anyone believe it? Was it ever supposed that any man believed an advertisement? Sit down and write the truth, and see what it will be! The statement will show itself of such a nature that you will not dare to publish it. . . . Did you ever believe an advertisement? ... And why should others be more simple than you? No man, - no woman believes them. They are not lies; for it is not intended that they should obtain credit. I should despise the man who attempted to base his advertisements on a system of facts, as I would the builder who lays his foundation upon the sand. The groundwork of advertising is romance. It is poetry in its very essence. Is Hamlet true? . . . There is no man, to my thinking, so false . . . as he who in trade professes to be true. He deceives, or endeavours to do so. I do not. . . . Advertisements are profitable, not because they are believed, but because they are attractive. Once understand that, and you will cease to ask for truth." (Trollope 75-76; ch. 10)
\end{abstract}

He follows this up by creating enormous, stockinged wooden legs to advertise " 40,000 pairs of best French silk ladies' hose direct from Lyons"; looking at his handiwork he pronounces, "It is not true . . but it is a work of fiction, in which I take leave to think that elegance and originality are combined" (Trollope 76; ch. 10). Comparing his advertisements to fictions that are accepted as non-referential and non-informational, Robinson turns to the language of book reviews to construct a model of success in untruthful commercial speech that lies in its ability to be received as successful by a story-loving public. It is the reception, the social acceptance of the "not true," that finally undergirds the commercial corruption depicted in this parody.

It is, of course, Robinson's contention that there is no deception of the public but rather shared assumptions and expectations and even a shared basic knowledge of the parameters of truth and falsehood - and Robinson is a decidedly less-than-reliable narrator. On the one hand, therefore, the novel's satire invites readers to question this understanding as they laugh at Robinson's grandiose claims to genius; his dogged insistence on purveying falsehoods as the means to business success; and his treatment of his dishonest fictions (and their high cost) as ethically, as well as commercially, irrelevant to the failure of the firm. On the other hand, the novel's handling of Robinson as narrator is uncertain: Brown and Jones, the members of the firm who are concerned with the more (in principle) solid aspects of the business (its capital and the day-to-day running of the store), are represented stealing cash hand over fist, so that Robinson can seem almost merely naïve and idealistic by comparison and the critique of his role in generating commercial falseness is blunted. And as The Struggles of Brown, Jones, and Robinson parodies not merely dishonest business practices but also the exposé form that was intended to reveal them, the absence of a stable truth-teller undoes that genre's promise to give the behind-the-scenes story, "by one of the firm." Robinson makes gestures of disclosure into mere performances: at one point, for instance, he advertises the firm with an announcement, printed on a card delivered by footmen in magenta livery and emblazoned on the storefront, that Brown, Jones, and Robinson would charge a rate of profit half a percentage point higher than the rate of interest. The commercial forthrightness of the announcement's content is comparable to Trollope's own publication of his business practice and principles in his autobiography or his announcement as the St. Paul's Magazine editor. The 
over-the-top delivery mechanism with which this forthrightness is coupled might mark a distinction between the parody disclosure and the more sober, real-world example from Brown Jones and Robinson's creator. But it also dissolves that distinction, suggesting that such disclosures are as likely to be mere gestures of forthrightness, hand-in-glove with promotional intentions, as honest efforts to inform. And because the glove that delivers the message is, in effect, magenta - showy and ridiculous - the parody version demands immediate recognition of this possibility. There is no excuse not to know, in such a formulation, that straightforward information is not necessarily what it appears, and the presumption should hold even when that information is delivered by a plain-spoken, prosaic messenger.

\section{Conclusion}

BEFORE FACEBOOK'S IPO, THERE were parodies: from videos by established internet comedy sites, to individually produced You Tube efforts that set the story of The Facebook IPO to the tune of "The Farmer in the Dell." "Even as they depict young, monocle-wearing Facebook employees blowing their noses with dollar bills, the laughter that these parodies elicit (some more than others) highlights the audience: the spectacle, the widespread interest, the excitement to purchase shares and to see how high they might go. Nowhere is there a sign of the controversy to follow, in which the audience - the market for the parodies, for the shares, and for stories about the shares - was suggested to be unequally divided.

The engagement of the audience in the parodic mode - as a rhetorical feature, a formal effect, and as a subject - generates critical energies, but also presents risks. Acknowledging the role of audience participation in enabling business fraud - like the stage performers do, playfully, and like Trollope does, more savagely - may discount the very real asymmetries of information and power that condition participation in investment and in the market more generally. As the examples of parody I have discussed suggest, this style of "knowingness" was available and deployed, sometimes to very powerful effect, across the market. This knowingness does not deconstruct or defamiliarize a social or ideological norm or structure or at least not in any way that can be considered significantly progressive. Instead, the knowingness helped enable the rituals and material transactions of Victorian capitalism by giving its audience a way to live with those asymmetries of information, in particular: to accustom themselves, to excuse, to self-blame. As it shapes the informational frameworks that undergird markets, parody reminds its audiences of the power of information but leaves the responsibility in their hands. After all, they knew all along - or they should have - that there was probably more to know.

In the still-ongoing aftermath to the 2008 financial crisis, Victorian lessons about the temptations and risks of parody may be ripe for relearning, and the appeal of the parodic mode has been supplemented with a wary sense of its limitations. I close with a brief discussion of the mode's appearance in Adam McKay's The Big Short (2015), a film adaptation of Michael Lewis's nonfiction account of the crisis, which turns the referential aesthetic that characterizes parody inside out to insist on the ways we are not all equally in on the joke. The film's celebrity cameos teach lessons in recent economic history: Selena Gomez joining behavioral economist Richard Thaler at a blackjack table to give a mini-lesson on collateralized debt obligations, Margot Robbie in a bubble bath explaining subprime 
mortgage markets. The comic juxtaposition of abstruse financial topics with figures who overtly signal broad commercial appeal - Gomez is not only an "International Pop Star," as the film's captions identify her, but an ex-Disney star; Robbie is conventionally beautiful and gratuitously naked - highlights the audience as audience. But even as viewers are positioned as part of a mass market, we are reminded that we do not all occupy markets the same way. We do not all share the same information. We haven't, to recall Trollope's phrasing, "known all about it before."

The parodic referentiality of Robbie's cameo, in particular, subjects the tropes of guilty audience participation to scrutiny. In using Robbie, who played the wife of Jordan Belfort (Leonardo DiCaprio), the "Wolf of Wall Street" in Martin Scorsese's 2013 film of the same name, The Big Short implicitly recalls that earlier film's account of market excess. But where The Wolf of Wall Street constructs complicity, through scenes in which onscreen audiences join with the film's viewers in witnessing and enjoying the performative, over-the-top financial bad behavior of Belfort and his crew of latter-day Affable Hawks, McKay's scene underscores the limits of that critique. In The Wolf of Wall Street, Robbie's character's flagrant nakedness, framed in a doorway as she seduces Belfort, emblematizes both hustle and the desire that shapes and motivates it, and Scorsese's camera enlists the film audience in that desire. But even as the sight of Robbie's body - in an opulent bath, drinking champagne served by a butler's hand - parodically repeats Scorsese's invocation of desire and excess, The Big Short undoes parody's reliance on knowingness and redirects its critical aim. The scene constitutes its viewers as market subjects who are savvy enough to get the references and who are susceptible to shared desire. But it simultaneously emphasizes a dynamic of concealment and exposure that restores information - and its manipulation and unevenness - to its central role in the crisis. Explaining the subprime sleight-of-hand in her own Australian accent rather than her character's Brooklynese, Robbie replaces the performance of seduction that is assumed to be part of the audience's knowledge with a lecture that turns to the real. The bubbles that hide her reference communal desire, but they are not created by that desire, notunlike the prices of tickets to Melmotte's ball, or the credit generated for Magenta House by Robinson's stories, or the very fine and large music-hall songs - inflated by an eager and aware public. These bubbles have been put in place, piled thick and high, a charged visual emblem of constructed lack of transparency. Direct explanation - an acknowledgement that we are not all, already, equally knowing - may be a necessary counter to the rueful recognitions of parody in The Big Short's evaluation of how information makes markets. But remaking markets, the film insists, requires recognizing that the imbalance of information is a persistent function of unequal power. Information may be a tool to combat economic injustice. But it can't be the only one. And as information is deployed in different forms, from lecture, to exposé, to parody, we must take care not to allow its spread to obscure or misplace distinctions of responsibility.

Boston College

\section{NOTES}

1. It hardly needs saying that Poovey's book has generated significant critical discussion; see, for instance, Henry 2015, and Kreisel 2012, and Kornbluh 2014. For one response that specifically addresses the concept of information in her argument, see Robbins 2009. 
2. Butler's Gender Trouble: Feminism and the Subversion of Identity (New York: Routledge, 1989) provided a template for many arguments that take this approach. Other theorists of parody have been more circumspect about its critical force; Hutcheon, for instance, has argued that parody has a tenuous relationship to social criticism, remaining self-referentially directed toward art, rather than outwardly directed toward the social world as satire is. Hutcheon and Williams both have suggested that parody can have a "conservative" force as it keeps in view the older forms from which it builds; see Hutcheon, 26 , and Williams, $x$. For an account of nineteenth-century satire that distinguishes varying orientations toward truth-telling and social correction, see Matz.

3. For an astute discussion of Victorian fraud, see Stern.

4. For an excellent analysis of dramatic representations of Victorian commerce that makes the case for theater as a crucial, overlooked analytical site, see Moody.

5. For a discussion of the history of the display of nakedness in Mazeppa and its economic and entrepreneurial significance, see Davis chap. 4. Davis's work is invaluable for understanding the nuances of commercial roles in theatrical entertainment, which were often described with ambiguous and overlapping terminology; see 164-67.

6. For the identities of the playbill characters, see Davis 50-51; Bolton 311, 335.

7. Manager and chairman were, in the earlier years, often the same person, but the two roles later split apart into separate onstage and offstage parts (Garrett n.p.).

8. On the historiography of music hall, see especially Bailey, who traces and complicates the conventional narrative of music hall's evolution from authentic popular culture to "the growth industry of commercialised modern leisure" ("Custom" 185) as new ticketing, seating, architecture, and labor relationships were introduced by these promoters.

9. Over the decades performers also moved between the stage and offstage managerial roles such as agent or promoter, blurring the lines as well (Newton).

10. Contemporary observers of music hall also highlighted this mode; in his memoir Idols of the 'Halls,' for example, Newton mentions as a "well-known music-hall catchphrase" the reiterated line "believe me, or believe me not," popularized by the comic singer Dan Leno (71).

11. On the politics of joint-stock companies and pressures for and against "democratic" shareholder control, see Alborn. Many contemporary examples represent shareholders in terms of their relation to information. "A Grammar for the Use of Railway Companies," in Fun, flippantly analyzes shareholders as consonants and directors as vowels, saying of shareholders "some might be called mutes, others semivowels, who utter an imperfect sound at half-yearly meetings, and others liquids, from their readiness to adjourn for refreshment. Shareholders cannot be called syllables or words, not often acting with a single impulse, and their sounds being frequently inarticulate, although they may be taken as signs of a prevalent idea of being deceived" (177). More seriously the Saturday Review represents the encounters between bank directors and shareholders at meetings as a closed, self-sanctioning informational circuit. At a moment when pressure to disclose is being brought to bear on the banks, they have not altered the form of their accounts, though "not because they have anything to conceal or think greater detail undesirable"; rather, they are waiting to see what legislators will prescribe in the way of changes in form. In any case, the writer declares, at the meetings the bank directors have self-regulated; they have "understood what the shareholders and the public wanted to know, and they supplied the information desired" (102).

12. On Trollope's negotiations with publishers see Hall 1992.

13. Anon., Saturday Review, 4 Mar. 1865, rpt. in Smalley, 216.

14. Other genres that the text parodies, the business biography and the business memoir, also had similar informational purport, though with less highly charged rhetoric and often with contradictory aims to burnish and celebrate the reputations of their subjects.

15. See the web videos "ZUCKERBERG: The Musical! Opus 3-May 15, 2012," "Inside the Facebook IPO," and "The Facebook IPO (Original Parody Lyrics to the tune: The Farmer in the Dell." 


\section{WORKS CITED}

Alborn, Timothy L. Conceiving Companies: Joint-Stock Politics in Victorian England. London: Routledge, 1998.

Auerbach, Nina. "Before the Curtain." The Cambridge Companion to Victorian and Edwardian Theatre. Ed. Kerry Powell. Cambridge: Cambridge UP, 2004. 3-14.

Bailey, Peter. "Custom, Capital, and Culture in the Victorian Music Hall." Popular Culture and Custom in Nineteenth-Century England. Ed. Robert D. Storch. London: Croom Helm, 1982. 180-208.

Bailey, Peter. Popular Culture and Performance in the Victorian City. Cambridge: Cambridge UP, 1998.

"The Bank Meetings." Saturday Review 25 Jan. 1879: 102-3.

Billy, Barlow. London, n.d. Harry Ransom Center, Austin, Tex. Sheet Music Collection, 18th c.-1964, Series I. Sheet Music, 18th-20th Century, Subseries B, 19th Century. Box 2, folder 3.

Bolton, H. Philip. Women Writers Dramatized: A Calendar of Performances from Narrative Works Published in English to 1900. London: Cassell, 2000.

Conder, F. R. "The Progress of Some of Our Railways Towards Bankruptcy.” Fraser's Magazine 18.106 (Oct. 1878): 490-502.

Davis, Tracy C. The Economics of the British Stage, 1800-1914. Cambridge: Cambridge UP, 2000.

Denisoff, Dennis. Aestheticism and Sexual Parody 1840-1940. Cambridge UP, 2001.

Donohue, Joseph. "Actors and Acting." The Cambridge Companion to Victorian and Edwardian Theatre. Ed. Kerry Powell. Cambridge: Cambridge UP, 2004. 17-35.

“The Facebook IPO.” YouTube. 16 May 2012. Web. 14 June 2013.

Faulk, Barry. Music Hall and Modernity: The Late-Victorian Discovery of Popular Culture. Athens: Ohio UP, 2004.

Fitzgerald, Percy. Music-Hall Land: An Account of the Natives, Male and Female, Pastimes, Songs, Antics, and General Oddities of That Strange Country. London: Ward, 1890.

Garrett, John M. Sixty Years of British Music Hall. London: Chappell and Company, 1976.

Gaskell, Elizabeth. Cranford. In Cranford/Cousin Phillis. Ed. Peter Keating. Harmondsworth: Penguin, 1986.

“A Grammar for the Use of Railway Companies.” Fun 17 Jan. 1863: 177.

"The Half-Yearly Railway Meetings." The London Review 27 Feb. 1864: 214-15.

Hall, N. John. Trollope: A Biography. Oxford: Clarendon, 1991.

Hall, N. John. Introduction to The Struggles of Brown, Jones, and Robinson, By One of the Firm. Ed. N. John Hall. New York: Oxford UP, 1992. vii-xv.

Henning, Peter J. and Steven M. Davidoff. “The Facebook I.P.O.'s Potential Legal Exposure.” New York Times 23 May 2012. Web. 14 June 2013.

Henry, Nancy. "2008 and All That: Economics and Victorian Literature." Victorian Literature and Culture 43 (2015): 217-22.

Hirschman, Albert O. "Rival Interpretations of Market Society: Civilizing, Destructive, or Feeble?" Journal of Economic Literature 20 (Dec. 1982): 1463-84.

Hunt, Aeron. Personal Business: Character and Commerce in Victorian Literature and Culture. Charlottesville: U of Virginia P, 2014.

Hutcheon, Linda. A Theory of Parody: The Teachings of Twentieth-Century Art Forms. New York: Methuen, 1985.

“Inside the Facebook IPO.” Jest.com. Web. 14 June 2013.

Kornbluh, Anna. Realizing Capital: Financial and Psychic Economies in Victorian Form. New York: Fordham UP, 2014.

Kreisel, Deanna K. Economic Woman: Demand, Gender, and Narrative Closure in Eliot and Hardy. Toronto: $\mathrm{U}$ of Toronto P, 2012.

Laing-Measom, Malcolm. "How We 'Floated' the Trixie Gold Mine Co. (Limited)." Belgravia: A London Magazine 60.237 (July 1886): 44-56. 
Lewes, George Henry. The Game of Speculation. 1851. The Broadview Anthology of Nineteenth-Century

British Performance. Ed. Tracy C. Davis. Peterborough, Ontario: Broadview, 2012. 217-64.

Matz, Aaron. Satire in an Age of Realism. Cambridge UP, 2010.

McKay, Adam, Dir. The Big Short. Paramount, 2015.

Moody, Jane. “The Drama of Capital: Risk, Belief, and Liability on the Victorian Stage.” Victorian Literature and Finance. Ed. Francis O'Gorman. New York: Oxford UP, 2007. 91-109.

Newton, H. Chance. Idols of the 'Halls': Being My Music-Hall Memories. London: Heath, 1928.

Nocera, Joe. "Facebook's Brilliant Disaster." New York Times 26 May 2012. Web. 14 June 2013.

Poovey, Mary. Genres of the Credit Economy: Mediating Value in Eighteenth-and Nineteenth-Century Britain. Chicago: U of Chicago P, 2008.

Poovey, Mary. "Writing about Finance in Victorian England: Disclosure and Secrecy in the Culture of Investment." Victorian Studies 45.1 (Autumn 2002): 17-41.

Powell, Kerry, ed. The Cambridge Companion to Victorian and Edwardian Theatre. Cambridge: Cambridge UP, 2004.

"Railway Amalgamation." Saturday Review 28 Oct. 1871: 544-45.

"Reports from the Select Committee on Railway and Canal Bills; Together with the Minutes of Evidence, \&c. 1853." Edinburgh Review 100 (Oct. 1854): 420-61.

Robbins, Bruce. "Mary Poovey's Anxiety." Romanticism and Victorianism on the Net 54 (May 2009). Web. 14 June 2013.

Rusli, Evelyn M. and Michael J. De La Merced. "Facebook I.P.O. Raises Regulatory Concerns.” New York Times, 22 May 2012. Web. 14 June 2013.

Rusli, Evelyn M. and Peter Eavis. “Facebook Raises \$16 Billion in I.P.O.” New York Times 17 May 2012. Web. 14 June 2013.

Rusli, Evelyn M., Ben Protess, and Michael J. De La Merced. "Questions of Fair Play Arise in Facebook's I.P.O. Process.” New York Times 23 May 2012. Web. 14 June 2013.

Scorsese, Martin, Dir. The Wolf of Wall Street. Paramount, 2013.

Smalley, Donald. Ed. Trollope: The Critical Heritage. London: Routledge, 1969.

Stern, Rebecca. Home Economics: Domestic Fraud in Victorian England. Columbus: Ohio State UP, 2008. Trollope, Anthony. An Autobiography. Ed. David Skilton. Harmondsworth: Penguin, 1996.

Trollope, Anthony. The Struggles of Brown, Jones, and Robinson, By One of the Firm. Ed. N. John Hall. New York: Oxford UP, 1992.

Trollope, Anthony. The Way We Live Now. Ed. John Sutherland. 1875. New York: Oxford UP, 1991.

Williams, Carolyn. Gilbert and Sullivan: Gender, Genre, Parody. New York: Columbia UP, 2011.

"ZUCKERBERG: The Musical! Opus 3-May 15, 2012.” YouTube. 15 May 2012. Web. 14 June 2013. 